\title{
REVIEW
}

\section{Theoretical approaches to marine biogeography}

\author{
A. N. Golikov, M. A. Dolgolenko, N. V. Maximovich, O. A. Scarlato \\ Laboratory of Marine Researches, Zoological Institute, Academy of Sciences, Department of Ichtyology and Hydrobiology, \\ Leningrad State University, Leningrad 199 034, USSR
}

\begin{abstract}
There are 2 approaches in biogeography: landscape-geographic and flora-faunistic. The former is based on analysis of the quantitative distribution of organisms, which create a biological background to different areas. The flora-faunistic approach is based on comparison of the qualitative composition of all taxa in different parts of the areas. Biogeography is based on the principles of provinciality, zonality and the history of development and of genetic relations of taxa. Here the hierarchy of structural levels of life organization and biogeographical division of the World Ocean is considered. Dependence of organisms' distribution on the conditions, time and place of their origin are analysed. Differences in the character of species and higher taxa distribution are explained by different mechanisms of speciation and formation of higher taxa. Schemes of landscape and flora-faunistic biogeographical division of the World Ocean with detailed analysis of temperate and cold waters in the northern hemisphere are given.
\end{abstract}

\section{INTRODUCTION}

The results of many years' studies of biogeographical structure of the World Ocean testify to the approximate coincidence of the borders of biogeographical divisions marked out by different authors. On the other hand, the approaches of different researchers to understanding regularities in the distribution of organisms can be quite contradictory, depending not only on differences in the problems facing them, but also on the incompatible methodologies used by biogeographers. The need has arisen to summarize the data available and classify them in conformity with modern concepts in regard to the history of benthal formation in the oceans. The present paper deals with the trends prevailing in biogeographical investigations, summarizes their main results and discusses present-day problems in marine biogeography. It is based both on the authors' data and on the literature. Generalized schemes of biogeographical division of the Ocean or its parts are given in accordance with different approaches in biogeography.

(c) Inter-Research/Printed in F. R. Germany

\section{LIMITING FACTORS IN ORGANISM DISTRIBUTION}

Biogeography is the investigation of patterns in the distribution of organisms. The formation of distribution areas depends on organisms' ability to spread, which is limited by morphological and functional attributes of their organization. These attributes have developed as a result of evolutionary morphogenesis through adaptation to life in specific environments: sea (plankton, necton, benthos), land, fresh waters, air and on different sediments (hard or soft substrata). In the range of each phylogenetic group the distributions of species with similar morphological and functional structure and mode of life are limited by their specific responses to physico-chemical and, above all, temperature conditions, which regulate rates of physical and chemical reactions. In the process of speciation, genetic adaptation of organisms to specific abiotic conditions has developed. Ecophysiological adaptations are observed at the speciation level, while morpho-functional adap- 
tations become distinct during the emergence of higher taxa. To obtain an overview of the main trends in biogeographical division the mechanisms of speciation and formation of higher taxa should be considered in relation to their distributions.

Biogeographical division is based primarily on the distribution of species, their distributional areas determining the borders of biogeographical subdivisions.

A species structure is formed in the process of speciation as an ecophysiological adaptation with translation of phenotypic changes and selection to the genotypic level proceeding in response to large-scale environmental changes, primarily drops in temperature (Golikov 1973). The most sensitive stages in the life cycle of individuals (spawning, critical developmental stages) can proceed only under definite environmental conditions (Orton 1920, Runnström 1929, Kinne 1963, 1964,1970 ) similar to those during speciation. In many cases these stages of the life cycle define southern and northern borders of species distributions (Hutchins 1947) and reproductive areas. It is essential that the habitat temperature during spawning is close to the optimal temperature for the species (Golikov \& Scarlato 1973). All species whose origins coincide in place, time and conditions of initial adaptation respond similarly to changes in physical and chemical factors and, as a rule, have approximately similar geographical distributions and can be biogeographically grouped.

Physical and chemical environmental changes and formation of water masses (Defant 1929, Dobrovolsky 1961) precede speciation and cause emergence of new species. As a result, the species of each biogeographical group are associated in their distribution with a definite water mass, which gave rise to their formation, and comprise a hydrobiocomplex with this water mass (Babkov \& Golikov 1984). At the same time, within the whole distribution area of a species there exists a distinct interrelation between the genetically determined requirements of its individuals and the environment and distribution pattern that indicates a certain unity between the species and its environment, for which we propose the term 'ecogenocomplex'. Introduction of this notion appears appropriate in view of the ecological unity of a species and its environment in space and time. The first part of the term denotes the ecological aspect of a species, while the second part denotes its internal, genetically determined, environmental requirements. Since distribution ranges of species are often discrete the whole notion can be designated as a complex.

The distinct connection between the paleoecological situation during speciation and the limits on further distribution of species proved by paleontological material led to the proposal of an ecological principle of evolutionary reconstruction that would allow one to trace the time and place of species formation and their possible relations, even in the absence of fossils (Golikov \& Tzvetkova 1972).

The formation of genera and other higher taxa is caused by mechanisms besides speciation. During speciation, the adaptation of proteins and nucleotides to environmental physico-chemical conditions becomes established genetically by selection at the cellular and molecular levels. In the course of the formation of genera, families, etc, evolutionary morphogenesis comes to the fore and is realized by selection of phenotypes with morphological characters that correspond to the abiotic and primarily to the biotic environment. One of the most important biotic factors is food relations. Allied species with a resemblance in morphological adaptation to the biotic and abiotic environment obtain, via selection, similar morphological characteristics. According to similarities in the morphology and direction of specialization, relative species are grouped in genera, which, in their turn, form families, etc. According to the ecophysiological mechanism of speciation, which is usually neutral to morphological changes, allied species differ most clearly by non-adaptive morphological characteristics (Golikov 1980). The latter appear pleiotropically with ecophysiological adaptive attributes. With increase of taxon rank the adaptive role of morphological characteristics becomes obvious. The distributions of genera and taxa of higher rank have, as a rule, no association with distinct climatic zones. At the same time they may be adapted as a result of specialization to living in definite habitats and on certain types of relief and substrata. The distribution of higher taxa is mainly limited by such restricting factors as geomorphological, physical, chemical and spatial barriers. However, higher taxa which originated in relatively cold climates, later acquired their qualitative and quantitative development primarily in both temperate and cold waters (Golikov 1975).

As adaptive morphological specialization to certain biotic and abiotic conditions requires time, the taxonomic rank of endemism may be more or less associated with the time of taxa formation. The taxonomic rank of endemism is considerably influenced by the character of taxa formation. New taxa, allopatrically formed, appeared on the periphery of ancestral taxa areas, frequently simultaneously in different distant regions of the area. By contrast, in sympatric formation the differentiation of taxa occurred in adjacent places, but apparently at different times. Evidently the taxonomic rank of endemism depends both on the time of taxa origination and on the possibility of their further distribution. For example, off the Antarctic coasts, isolated from the shelves of other continents by vast aquatic areas with great depths. endemism is common at the 
family level, while in cold and temperate waters of the Northern Hemisphere, united by a nearly continuous shelf, endemism is rare even at the level of genera. Thus, the taxonomic rank of endemism cannot play a significant role in determining the rank of the considered biogeographical subdivision; the diversity of endimic elements, primarily species, seems to be of primary importance.

\section{HISTORY OF FORMATION OF THE RECENT BIOGEOGRAPHICAL STRUCTURE OF THE WORLD OCEAN}

The limits of geographical distribution of organisms in the geological past were determined, on the one hand, by the positions of the continents and, on the other, by differences in location of latitudinal-climatic zones. Up to the Cretaceous only several provinces are distinguished by different authors on the basis of investigation of distribution of various groups of organisms (Trilobites, Brachiopods, Graptolites, Nautiloides, fishes, Pangolins, etc; e.g. Hallam 1973). The distribution of organisms was considerably influenced by the unity of shelves; distribution of at least supraspecific taxa is rather wider than where they are separated by vast aquatic areas with great depths. The history of geomorphological development of the planet shows that the degree of lithospheric plate unity tended to decrease with geological time. While, during the Cambrian, Paleogondwana and the plates of North America and Europe were located mainly in the eastern part of the Southern Hemisphere, by the midCarboniferous the European platform moved into the Northern Hemisphere and Paleogondwana was separated from Protolaurasia by the narrow Paleotethys Sea (Zonenshain et al. 1976, Monin 1977). At the end of the Carboniferous the interconnection of lithospheric plates created conditions for wide distributions of organisms and a decrease in the number of isolated biogeographical subdivisions. However, the fall in temperature and glaciation during the Permian-Triassic period led to changes in many populations and caused a burst of speciation. For example, at this time a group of higher crustaceans appeared, the Peracarida, and in the recent cool Pleistocene epoch this group became widely distributed especially in the cold and temperate waters of the World Ocean. Significant climatic and evolutionary changes during the Carboniferous and Permian seem to have caused no origination of biogeographical subdivisions of higher rank because of the possibility of azonal distribution of higher taxa. During the late Triassic and beginning of Jurassic the splitting of Pangea began, together with the separation of Eurasia and North America from
Gondwana, which reached a position close to its recent one. As a result of reduction in the spreading out of tectonic plates in the Cretaceous and especially from the Cenomanian $(93 \pm 6$ million yr ago, approximately this time may be considered as the beginning of Cenozoic era), and strong climatic and evolutionary changes, large biogeographical subdivisions began to emerge. At this period at least 3 biogeographical regions, including 7 provinces, could be distinguished in the World Ocean on the basis of analysis of bivalve distribution (Kauffman 1973). Further changes in the distribution of life in the World Ocean were related to the increase in spreading of continental plates and strong differentiation of climatic conditions. The major stages of the process were separation of India and Australia from Antarctica in the Southern Hemisphere, and geological processes in the Faeroes-Greenland district in the Northern Hemisphere. Separation of Australia from Antarctica in the early Eocene (ca 56 million yr ago) caused water circulation around the latter and led to a temperature fall both in the Southern Ocean (down to ca $+14{ }^{\circ} \mathrm{C}$; Haq et al. 1977) and in the Northern Hemisphere. Families and genera which originated at that time have many recent representatives which are widely distributed in cold and temperate waters in both Hemispheres. The next significant event was the connection of the Indian subcontinent to Asia and the uplift of the Himalayas. The Tethys Sea ceased to exist as a transcontinental basin and, correspondingly, the direct exchange of populations between the Atlantic and Pacific Oceans stopped. As a result, later genera are not circumsubtropically distributed. Considerable temperature fall in the early Oligocene (ca 36 million yr ago) resulted in a subsequent rise of subtropical species, some of which exist even now. Cooling was relatively short and gave way to a temporary rise in temperature. Marine tropical fauna spread up to $50^{\circ} \mathrm{N}$ off the Pacific coast of America (Addicott 1969), while subtropical species lived off the shores of the Chukotski Peninsula and in the northern Okhotsk Sea off the shores of Asia (Dall 1893. Petrov 1976). The next important change in geomorphology and significant temperature fall took place ca 14 million yr ago at the beginning of a new geological epoch, the Boreocene (Golikov 1985a) which occupies the time from 14 to 5 million yr ago and corresponds to late Miocene of other authors. The Drake Passage off Antarctica gained depth and width, thus causing strengthening of the Southern Circular Current and initiation of surface glaciation of Antarctica (Baker \& Burrel 1977, Kvasov 1985). The above phenomena and general cooling caused the temperature of deep water in the northern part of the Pacific to fall to between +6 and $+7^{\circ} \mathrm{C}$ (Emiliani 1956, 1961, Savin et al. 1975). The initial recent boreal species 
originated there, giving rise to the Pacific boreal biogeographical region. At that time the climate and the flora-faunistic composition in the North Atlantic still remained subtropical. Approximately 5 million years ago (beginning of Pliocene) cooling, glaciation of Antarctica (Hayes \& Frakes 1975, Kennett 1977. Krasilov 1977) and mountainous glaciation in the Northern high latitudes intensified (Addicott 1969, Hopkins 1972). The temperature of surface waters in the North Atlantic fell to $8{ }^{\circ} \mathrm{C}$ in winter and 20 to $21^{\circ} \mathrm{C}$ in summer (Funnel 1970). Formation of the Atlantic boreal biogeographical region began. The initial boreal species, characteristic of the region off the European shores had a Mediterranean-Lusitanian origin. A powerful division of ocean ca 3.5 million yr ago and penetration of the Pacific boreal elements (with their consequent transformation into local species) into the North Atlantic mainly through the sea-covered north of Canada completed the formation of the above region. The further lowering of the average annual temperature to between +3 and $+6{ }^{\circ} \mathrm{C}$ (surface) and to between +2 and $+2.5{ }^{\circ} \mathrm{C}$ (bathyal) (Emiliani \& Flint 1963, Savin et al. 1975) in the northern Pacific boreal region (in many cases) and in the north-eastern part of the Atlantic boreal region (in rare cases) led to the formation of boreal-arctic species, which later acquired an interzonal distribution in Arctic and boreal waters.

Approximately 1.8 million yr ago, in the early Pleistocene, as a result of marked lowering of sea level, the Arctic Ocean became completely isolated from the Pacific and partially or completely from the Atlantic Ocean. Strong weakening or even cessation of the inflow of the North Atlantic Current into the Arctic Ocean seems to have been the major cause of surface glaciation in northern Europe and northwestern Asia up to the Taimyr Peninsula in conditions of low temperature and sufficiently high humidity. At that time the formation of a saline, moderately cold pseudoabyssal Arctic water mass and the emergence of corresponding endemic Arctic genera and species took place. The surface Arctic water mass was formed during the beginning of the division of the Ocean (ca $1.6 \pm 0.2$ million yr ago), and caused the origin of shelf Arctic endemics (e.g. Portlandia spp.). The relatively warm saline Atlantic-Arctic water mass occupied an intermediate position (at depths of 200 to $800 \mathrm{~m}$ ). Freshening of surface water during the beginning of the first interglacial period served as a base for the formation of an estuarine-Arctic water mass and its characteristic species (Golikov \& Averincev 1977a). Further glacial and interglacial changes of climate and sea level accompanied by migration of organisms completed the formation of the youngest Arctic biogeographical region. With relatively low environmental fluctuations in recent interglacial time only fluctuations in distribution and quantitative development of species and their disappearance from degrading ecosystems has taken place. For example, in the current century in the Barents Sea the distribution border of species different in their origin has changed by roughly 200 miles due to fluctuations in solar activity and intensity of the North Atlantic Current (Galkin 1986). As a result of ecosystem degradation in regions with reduced hydrodynamics in the White Sea, the Sea of Japan and elsewhere, previously common species either disappeared or became rare and biomass was reduced by 4 to 6 times in 10 to 20 yr (Golikov \& Scarlato 1979a, Golikov et al. 1986).

In the geological history of the planet there is observed a tendency to increasing separation of tectonic plates and increasing frequencies of epochs with distinct climatic changes. This leads to increase of heterogeneity in the geomorphological, physical, chemical and biological structure of the planet, as well as to increased detailing in its biogeographical division. The Southwest-northeastern direction appears to show the major trend in geomorphological and biological evolutionary transformations and further distribution of taxa. It is clear that continental movement could influence only the distribution of higher taxa, as the majority of recent species originated considerably later.

\section{PRINCIPLES AND APPROACHES IN BIOGEOGRAPHY}

Investigation of regularities in the distribution of life under different geomorphological and climatic conditions is an objective of biogeography. Due to specific characters and historical reasons marine organisms are associated with definite aquatic areas, which are relatively close to the centers of their origin and are separated by geomorphological or ecological barriers from floras and faunas of others aquatic areas. Correspondingly, the association of taxa distribution with separate regions of continents and oceans is the first general principle of biogeographical division.

Since latitudinal and vertical zonality in the distribution of environmental conditions is a natural quality of the planet, zonality in organism distribution is a second important general principle of biogeography when examining any trend. Polar zones of the North and South Hemispheres, temperate zones (boreal in the North and notal in the South) and a tropical one with subtropical subzones are clearly distinct. Vertical zonality in the flora-faunistic composition within each latitudinal zone is determined by changes with depth and the character of convection, water mass and dominating forms of relief.

\footnotetext{
- notal = temperate waters of Southern Hemisphere
} 
The third principle of biogeographical division is based on studying the relations between species, genera and higher taxa. The principle also involves analysis of the origin, spread and probable reasons for isolation and extinction of separate taxa and whole floras and faunas.

From the beginning of the formation of biogeography as a special branch of science there have been 2 major approaches: the landscape-geographical approach, based on quantitative analysis of the distribution of dominant species or life forms, creating the biological background for landscapes of different regions, and flora-faunistic (or historic-genetical) approach, based on qualitative analysis of the composition of floras and faunas of different regions and on the analysis of their origins. While the historic-genetic approach in biogeography deals with the study of all areas of species and higher taxa, the landscape-geographical one considers only those parts of areas where the taxa form large biomasses and are capable of organising the background landscape. The flora-faunistic or genetical approach includes all species, even those which are represented by a single record, while the landscapegeographical one regards only species which form large biomasses on vast areas. Such an ability is characteristic of eurybiontic species with a wide distribution. Maximum biomasses are formed by background-creating species in conditions which are more favourable for them than for many other coexisting species.

\section{Landscape-geographical approach}

Subdivisions of the biological background of landscape have a hierarchical structure (Fig. 1). The elementary unit of biosphere is the individual (Fig. 1, 1), which is incapable of self-reproduction in most hydrobionts, cannot create a biological background and, therefore, is not an element of landscape biogeography. An individual in space and time forms a monocene (Schwerdtfeger 1968) and occupies a monotope (Fig. 1, 2). The first biologically functional element of the system level of organization of individuals, capable of exchange with gametes and energetic information along the life cycle, is a population (Fig. 1,3). A population forms a democene characterized by predominance of certain phenotypes and occupies an ecotope in accordance with the ecological niche of a species (Fig. 1,4) (Wittaker et al. 1973). Depending on the size, life span, individual mobility and position of ecological or geographical barriers, populations may occupy areas from several $\mathrm{cm}^{2}$ (microorganisms, mesoorganisms) up to thousands of $\mathrm{km}^{2}$ (migrating fishes, marine mammals). In connection with variability of conditions a population is represented by a characteristic settlement occupying a particular area.

Populations of coexisting species are organised so that one or a few species dominate many others significantly in their biomass and other bioenergetic indices. This level of species organization is called a biocoenosis (Fig. 1, 5) (Möbius 1877). The predominance of some species over others in marine biocoenoses was later quantitatively determined (Petersen \& BoysénJensen 1911, Petersen 1913). A biocoenosis occupies a biotope (Dahl 1908), the limits of which are marked by the ranges of domination of the chief species in the biocoenosis. The biocoenosis and the biotope constitute the functional unity of the ecosystem (Fig. 1,6) (Tensly 1935).

Biocoenoses with the same chief species but separated by spatial or ecological and morpho-geological barriers, which prevent their direct bioenergetic exchange, are grouped into associations (Fig. 1, 7) (Humboldt 1805). These represent the third hierarchial level of the landscape's biological component. Associations comprise representatives of both plant and animal kingdoms (Griesebach 1838, Flahaut \& Schröter 1910, Shelford 1932, 1945, 1970). Together with the physical and chemical environment, associations are included into facia (Fig. 1,8) which unite similar biological forms with relief composed of sediments similar in their

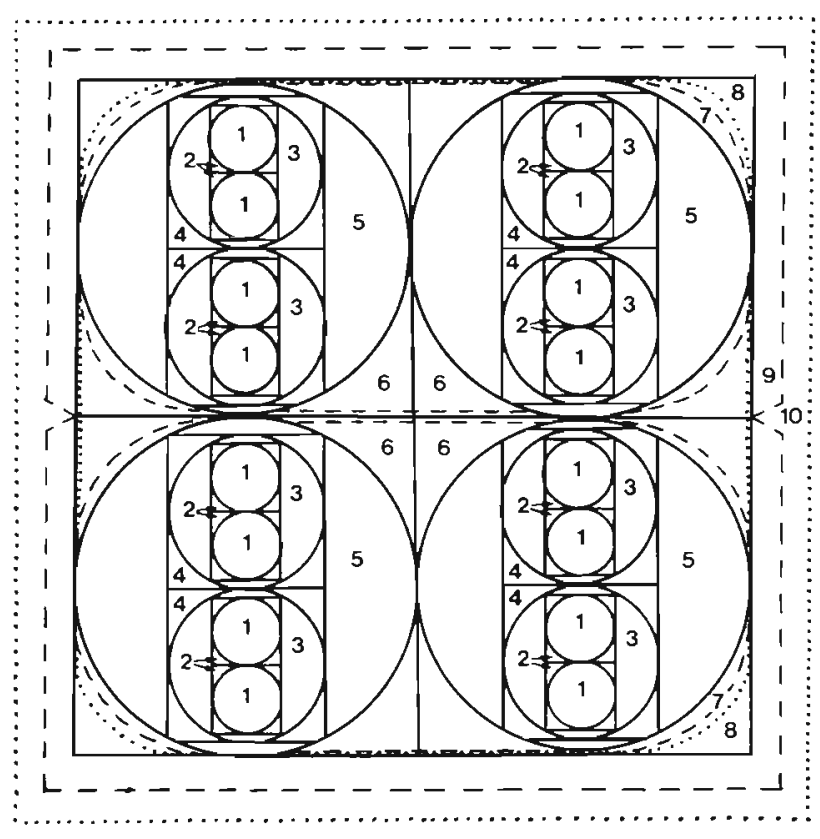

Fig. 1. The hierarchial scheme of elements in landscape division. 1, Individual; 2, monocene + monotope (Schwerdtteger 1968); 3, population (see text); 4, democene+ecotope (Wittaker et al. 1973); 5, biocoenosis (Möbius 1877); 6, ecosystem (Tensly 1935); 7, association (Humboldt 1805); 8, facia (Derjugin 1915); 9, biome (Clements \& Shelford 1939): 10, formation (Griesebach 1838) 
petrographic composition (Gressly 1838, Derjugin 1915, Clements \& Schelford 1939, Golikov \& Scarlato, 1979b). For example, associations are formed by species of marine grass (e.g. Zostera marina), algal belts (e.g. Laminaria saccharina), bivalves (e.g. Mytilus edulis) or corals in the tropics (e.g. Porites lobatus), which are facia indices on the large spaces of sea bottom. Under similar physical and chemical conditions, associationforming species produce approximately the same biomass in different ecosystems (Golikov \& Scarlato 1982), thus facilitating considerably the estimation of biological resources on large spaces of the sea bottom. Within the limits of one latitudinal zone in different oceans and their opposite shores, as well as in latitudinal zones with relatively similar conditions in different hemispheres, there often exist parallel associations in which the leading roles belong to relatively close species (Thorson 1958). These associations possess comparable biological resources.

Associations organized by species with similar morpho-functional characteristics and role in nature (i.e. consisting of the same life form), are united in biomes (Shelford 1932, Clements \& Shelford 1939) (Fig. 1, 9), thus forming the fourth, and most stable biological hierarchial landscape level. Biomes, together with the environment, are consolidated in formation (Fig. 1, 10). The latter often include geographically and biologically heterogeneous structures of different geological age, though with similar physical, chemical and biological characteristics (Griesebach 1838, Clements 1905, 1916, Clements \& Shelford 1939, Golikov \& Scarlato 1979b). The modern marine biomes are represented by various species, genera and sometimes even families of marine grasses, laminarians, fucoids, mussels, oysters, corals, etc. The number of formations in bodies of water is limited by the quantity of life forms possible under given geomorphological, physical and chemical environmental conditions. Thus, in Arctic conditions the number of formations is far less than in temperate ones, and in temperate conditions is less than in tropical ones. Distribution of major formations on the shelves in temperate and cold waters of the Northern Hemisphere is given as an example (Fig. 2).

Within the parts of oceans defined by changes of facia there may be distinct localities, the characteristic distribution of which forms landscapes. In Russian literature the landscape approach to marine biogeography is reflected in the geographic aspect of works by Petrov (1974), Gurjeva et al. (1976), Golikov \& Scarlato (1976, $1979 b)$. It has been quantitatively expressed on biological material in a far larger number of investigations (Zenkevitch 1947, Vorobjev 1949, Shorygin 1955, Bogorov 1967, Beklemishev et al. 1977, Golikov \& Averincev $1977 \mathrm{a}, \mathrm{b})$. Marine landscapes extend both horizontally and vertically and change with depth in accordance with changes of hydrological conditions and geomorphology of the sea bottom (Andriashev 1974, Golikov 1985b). With depth, landscapes may be subdivided into floors, horizons, belts and zones. As a rule, facia occupy certain floors or horizons, while formations occupy belts or zones, more or less equivalent to the latitudinal ones. According to the landscape principle, the benthal zone is subdivided into the supralittoral (Lorenz 1863), the littoral (Forbes 1840), characterized by formations of fucoids, littorinids, neritids, mussels and barnacles; the sublittoral (Lorenz 1863) with macrophyte formations, which in its turn is subdivided into circumlittoral with predominance of laminarian algae or marine grasses or madreporarian corals (the latter in the tropical latitudes), the median zone, characterized by predominance of red algae, and the inframedian zone with mass development of Cnidaria, Bryozoa and Spongia (Forbes \& Hanley 1853). Formations of the inframedian zone occupy by the range of depths the same areas of the sea bottom as the elittoral (Kjellman 1877). On the continental slope, i.e. in the bathyal, bathybenthal formations are distinguished down to depths between 1200 and $2000 \mathrm{~m}$; below there are ocean-bed, i.e. abyssal, formations (Appellöf 1912).

As an example the discussion is illustrated by schemes of distribution of shelf formations in the relatively well-studied temperate waters of the northwestern part of the Pacific Ocean (Fig. 3) and of the North Atlantic and neighbouring waters of the Arctic Ocean (Fig. 4). These schemes are based on the authors' extensive observations and literature data. The method proposed is convenient and gives informative results of research of pattems of life distribution within landscape and facilitates their analysis. The method is based on the study of distribution of background-forming organisms within biomes of the shelf. Vertical boundaries of biomes show their limits at different latitudes.

\section{Flora-faunistic genetic approach}

This approach in biogeographical studies, based on qualitative analysis and comparison of floras and faunas, developed somewhat later than the landscapegeographical trend. The bases of the faunistic approach in the biogeography of the World Ocean were first laid down by Schmarda (1853), who compared the specific composition of faunas in different climatic zones, and by Ortmann (1896), who carried out biogeographical analysis of the distribution of decapods. The modern stage in this trend in biogeography was begun by Ekman $(1934,1935,1953)$, who used all 3 principles (provinciality, zonality, history) in global 


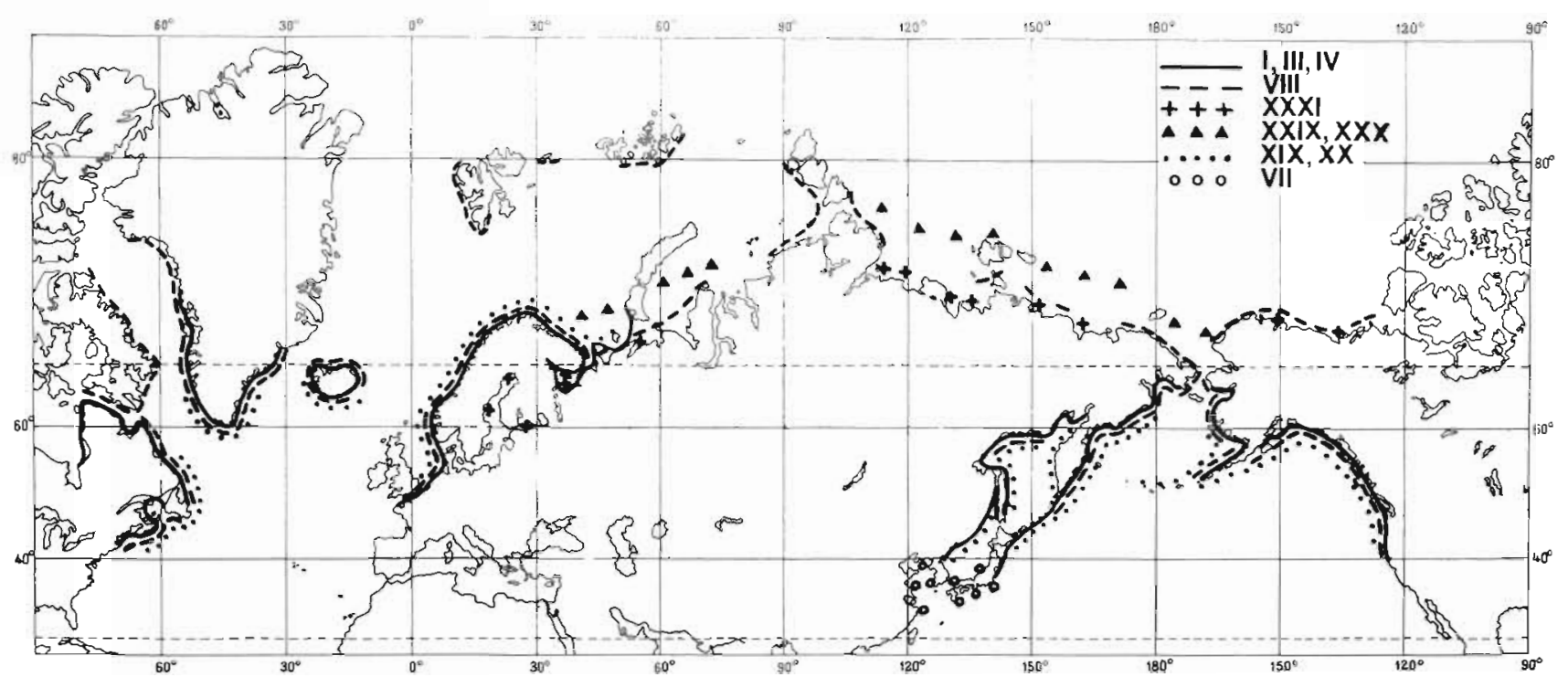

Fig. 2. Distribution of major formations in the kingdom of temperate and cold waters of the Northern Hemisphere. I - Littorinids: 1, Brevilittorina brevicula; 2, B. mandshurica; 3, Neritrema kurila; 4, N. sitchana; 5, N. obtusata; 6 , Littorivaga saxatilis; 7 , Littorina squalida; 8 , L. littorea. Il - Barnacles: 9, Chthamalus dalli; 10, Semibalanus balanoides; 11 , Balanus cariosus; 12, B. crenatus; $13, B$. balanus; 14 , Verruca strömi. III - Fucoids: 15 , Pelvetia wrighti; 16, P. canaliculata; 17, Fucus distichus; $18, F$. vesiculosus; 19. Ascophyllum nodosum. IV - Mussels: 20, Mytilus coruscus; 21, Crenomytilus grayanus; 22 - Mytilus edulis; 23, Modiolus difficilis; 24, M. modiolus. V-Oysters: 25, Crassostrea gigas. VI - Amphipods (Gammaridae): 26, Anisogammarus spp.; 27. Gammarus spp.; 28, G. setosus; 29, G. wilkitskii. VII - Sargassum algae: 30, Sargassum miyabei; 31, S. pallidum. VIII Laminarian algae: 32, Laminaria japonica; 33, L. cicchorioides; $34, L$ bongardiana; 35, L. saccharina; 36, L. hyperborea; $37, L$. digitata; 38, L. solidungula; 39, Alaria fistulosa; 40, A. esculenta. IX - Red algae: 41, Ptilota filicina, Phycodris sinuosa, Delesseria sanguinea, Pt. plumosa, Odonthalia dentata, Ahnfeltia plicata, Phyllophora brodiaei. X - Sea anemones: 42, Metridium senile; 43, Tealia felina. XI - Regular sea urchins: 43, Strongylocentrotus nudus; 44, S. intermedius; 45, S. droebachiensis; 46, S. pallidus; 47. Echinus esculentus. XII - Ascidians: 48. Halocynthia roretzi; 49, H. aurantium; 50, Styela spp.; 51, Molgula spp. XIII - Sponges: 52. Geodia spp.; 54, Polymastia spp. XIV - Soft corals: 54, Gersemia spp.; 55, Cerianthus spp. XV - Marine grasses: 56, Zostera marina; 57, Z. asiatica; 58, Z nana; 59, Phyllospadix iwatensis. XVI - Sand hoppers (Talitridae): 60, Talorchestia spp., 61, Orchestoidea spp. XVII - Bivalves (Tellinidae): 62, Macoma incongrua; 63, $M$. orientalis; $64, M$. calcarea; $65, M$. moesta; $66, M$. balthica. XVIII - Bivalves (Myidae): 67, Mya japonica; 68, M. arenaria; 69, M. truncata. XIX - Bivalves (Mactridae, Arcticidae): 70 , Spisula sachalinensis; 71, Mactra sulcataria; 72, Arctica islandica; and others. XX - Bivalves (Pectinidae): 73, Mizuhopecten yessoensis, 74, Chlamys farreri; 75, C. beringiana; 76, C. albida; 77, C. islandica. XXI-Flattened sea urchins: 78, Scaphechinus griseus; 79, S mirabilis; 80, Echinarachnius parma. XXII - Epifaunal sedentarian polychaetes: 81, Bispira spp.; 82, Polydora spp. XXIII - Polychaetes: 83, Arenicola spp. XXIV - Errantian polychaetes: 84, Nereis spp., Nephtys spp., Lumbriconereis spp., and others. XXV - Infaunal sedentarian polychaetes: 85, Pectinaria spp., Maldane spp. XXVI - Irregular sea urchins: 92, Echinocardium cordatum; 93, Brisaster fragilis. XXVIII - Starfishes: 94, Ctenodiscus crispatus; 95, Urasterias linckii; and others. XXIX Bivalves (Astartidae): 96, Tridonta borealis; 97, Nicania montagui; 98, Astarte crenata; and others. XXX - Bivalves (Nuculanidae): 99. Nuculana pernula; 100, Portlandia arctica; and others. XXXI - Isopoda, distributed in the Estuarian-Arctic water mass: 101,

Saduria entomon; and others

biogeographical division of the World Ocean. He also evaluated endemism, characteristics distribution and relation not only between species, but between higher taxa as well. These investigations were further developed by the analysis of the distribution and centers of origin of whole floras and faunas and separate systematic groups in different parts of the World Ocean (Gurjanova 1951, 1964, 1972, Berg 1947, Zynova 1962, Golikov 1963, 1980, Beklemishev 1969, Lindberg 1972, Briggs 1974, Vassilenko 1974, Tzvetkova 1975, Kussakin 1979, Scarlato 1981, Piccolli 1984, Vinogradova 1984, Nesis 1985). The biogeographical analysis of floras and faunas, based on the qualitative comparison of the composition of species and higher taxa generally accompanies revision of large systematic groups and contributes to monographs on evolution and ecology.

The flora-faunistic approach is based on comparison of the composition of all elements of floras and faunas in different water bodies and their parts. The florafaunistic composition (in a broad sense) implies qualitative diversity of species and higher taxa, which differ by place and conditions of their origin and, consequently, by their distribution. The location of taxa origin generally coincides with the highest diversity of elements included (individuals and morphs in a species, species in genera, etc). Ecological and geomorphological barriers block the spread of organisms from their place of origin and lead to diverse composition of floras and faunas in various localities. Correspondingly, the locations of taxa origins determine 


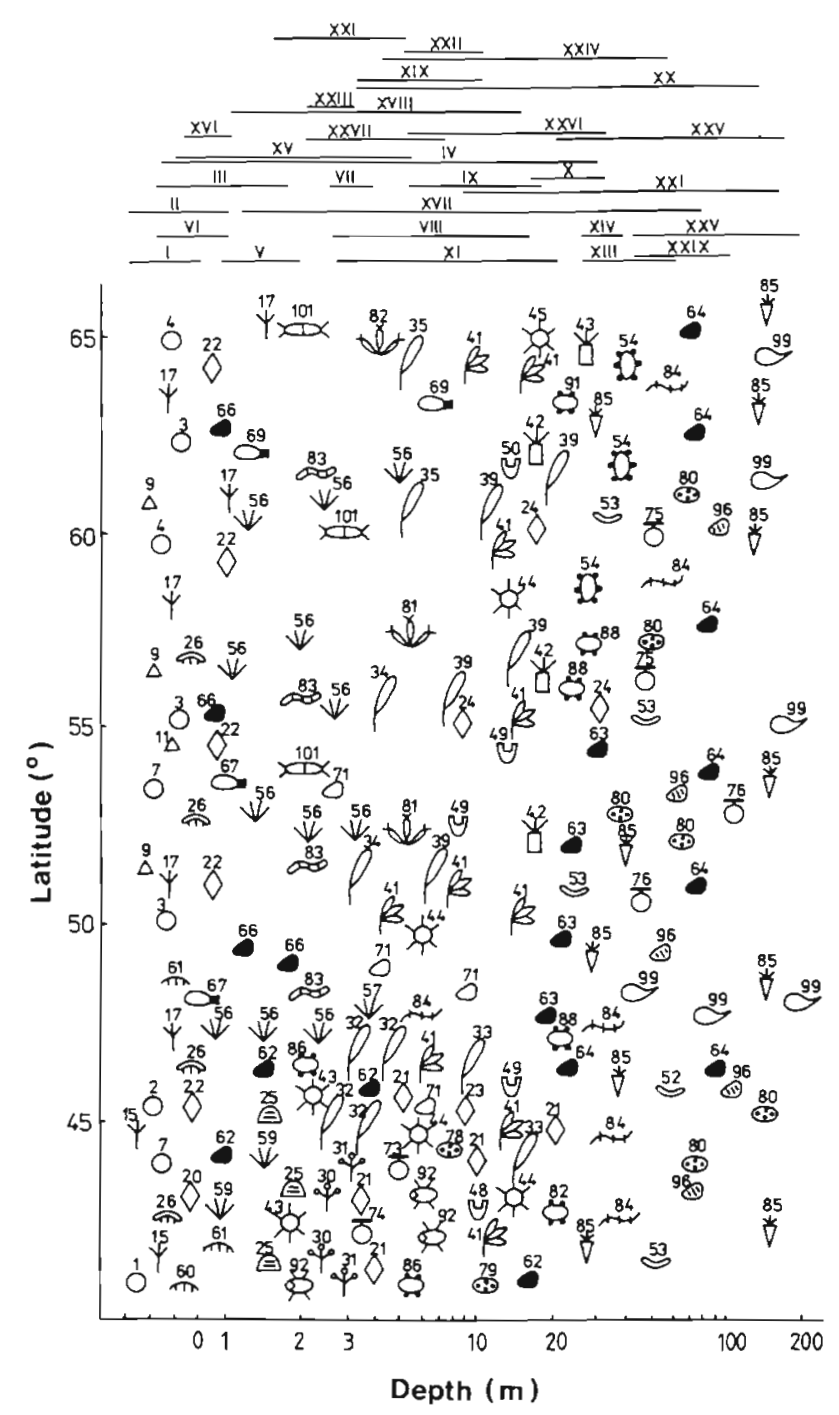

Fig. 3. Distribution of the formations of the marine landscape in the temperate waters of the north western Pacific. Formations as in Fig. 2

their thermopathy and adherence to certain climatic and hydrological belts and latitudinal zones. The determination of the rate and rank of endemism in a part of a water body is important for evaluation of the rank of biogeographical subdivision. Subdistricts appear to be the first units in flora-faunistic biogeographical division. Districts represent the next subdivision of the species composition; a district is characterized by the presence of original intraspecific forms. Endemic species are often peculiar to the province, that usually occupies much a greater area. Provinces are grouped into subregions, for which endemic genera may be characteristic, and are included into regions, which frequently have endemic families. Biogeographical super-regions may contain original orders, while kingdoms may include even whole classes (e.g. Xiphosura in the tropics).

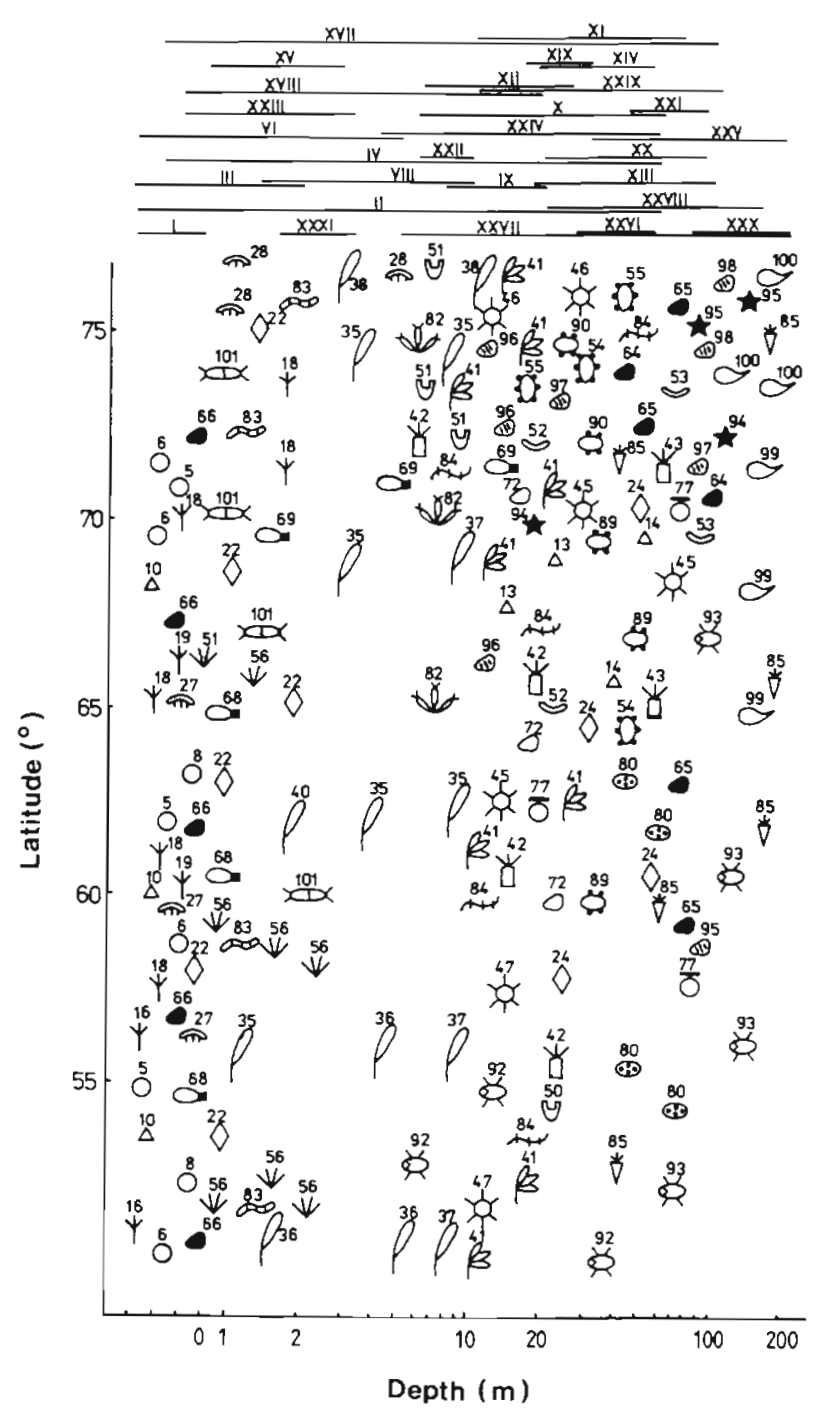

Fig. 4. Distribution of formations in temperate shelf, waters of the North Atlantic and neighbouring waters of the Arctic Ocean. Formations as in Fig. 2

The scheme of large-scale biogeographical zonation of the World Ocean is given in Fig. 5. The World Ocean is divided into 3 kingdoms. Most authors divide the Tropic kingdom into 5 regions (Ekman 1935, 1953, Gurjanova 1972), which are united into the Indo-WestPacific (1, 2), Mediterranean-North African (3) and Guinea-Caribbean $(4,5)$. In our opinion, the Tasmanian (6), New Zealand (7), South African (8), Patagonic (9) and Araucanic subtropical regions (10) should be included in the same kingdom. Due to the level of similarity in flora-faunistic composition and to the closeness of geographical position they can be united into Tasmanian/New Zealand, South African and Patagonic-Araucanic super-regions. Previous authors included these regions in the kingdom of temperate and cold waters of the Southern Hemisphere. However, by the climate of neighbouring continents, the sea- 
Fig. 5. Scheme of biogeographical division of the World ()cean on flora-faunistic genetical basis. A: borders of kingdoms; B: borders of regions (supposed borders of large biogeographical subdivisions beyond the limits of shelves and in uncertain cases are shown by a dashed line). 1 West-Pacific tropical; 2, Indian Ocean tropical; 3, Mediterranean-Lusitanic subtropical; 4 Guinean tropical; 5 Carribean tropical $_{i} 6$, Tasmanian subtropical; 7, New Zealand subtropical: 8, South African subtropical; 9, Patagonian subtropical; 10, Araucanic subtropical; 11, Kerguelenic notal; 12. Antarctic; 13, Pacific bore$\mathrm{al}_{i}$ 14, Atlantic boreali 15 . Arctic

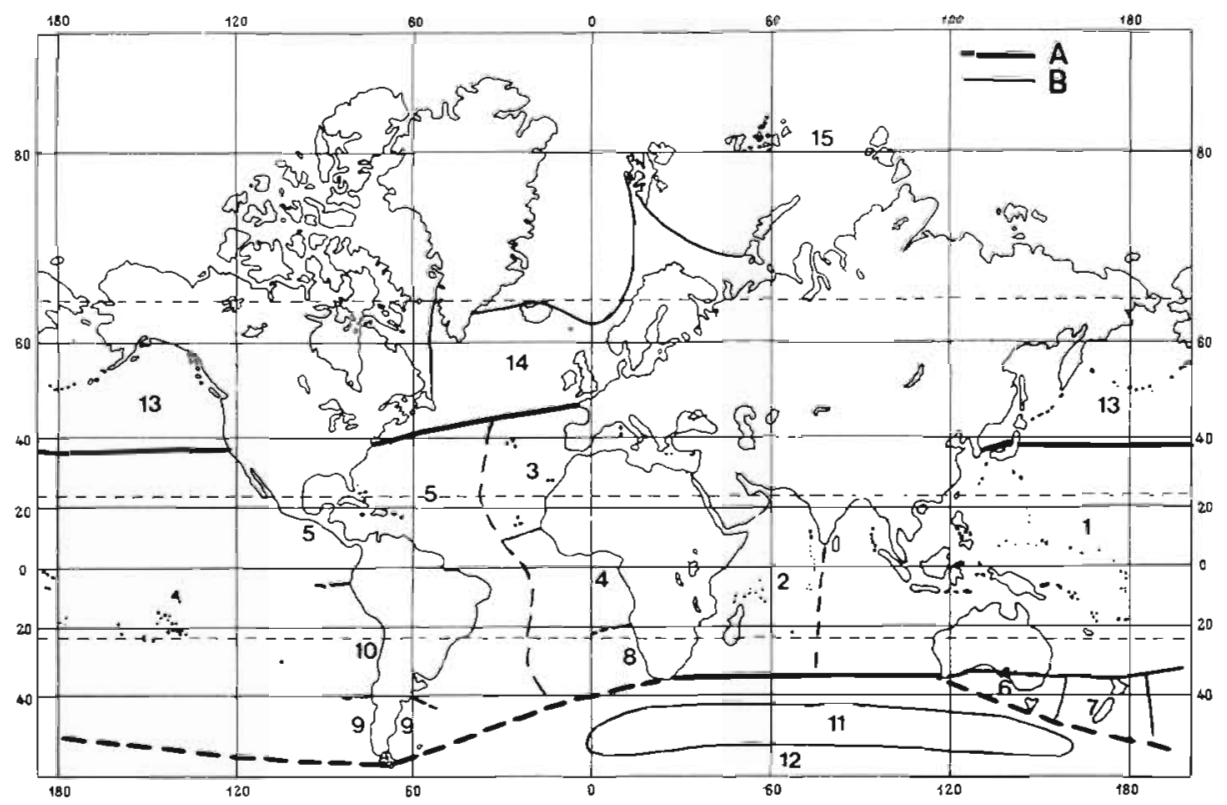

atmosphere heat exchange, hydrological regime and the composition of families and genera, the largest part of each of the above regions is located in the subtropical subzone of the tropical zone. The flora and fauna of the shelves in these regions are generally characterised by a thermophilic nature. At the same time, in deeper waters of the regions, taxa with chiefly notal-antarctic distributions are usual. The southern parts of the shelves of New Zealand and South America have more elements in common with notal and antarctic waters than its northern parts and their flora and fauna are of transitional character.

According to the scheme suggested and in conformity with the position of the notal and antarctic climatic belts and antarctic and subantarctic convergences, the Kerguelenic notal (11) and Antarctic (12) regions are the only constituents of the temperate/cold kingdom of the Southern Hemisphere. The small number of regions in this kingdom can be explained by the isolation and cohesion of the continental shelf of Antarctica and of island shelves and by a relatively closed circulation of waters of the Antarctic and the Subantarctic.

The Pacific (13) and Atlantic (14) boreal regions and Arctic region (15) are related to the temperate/cold kingdom of the Northern Hemisphere. Some authors include only 2 regions in this kingdom, as they consider the Arctic a subregion of the Atlantic boreal region (Kussakin 1971, 1979, Nesis 1985). The well-studied temperate/cold kingdom of the Northern Hemisphere is given as an example of more detailed biogeographical subdivision (Fig. 6). In the Asian low-boreal subregion of the Pacific boreal region only the shoals (down to 25 to $30 \mathrm{~m}$ ) of Aniwa and Terpenia Bays
(Sakhalin) are related to the Kuril-Sakhalin province, while the deeper waters of these bays are included into the Okhotsk Sea province of the high-boreal subregion. In each province the localities and the districts characterized by the species composition are distinguished. For example, in the Primorsk province the South-Primorsk district, which occupies the whole of Peter the Great Bay, is distinguished. Within this district in the semi-enclosed bays and lagoons, well heated in summer, subtropical species dominate, while near the relatively open coasts most species are of boreal origin (Golikov \& Scarlato 1967, 1968). Thus the protected bays and lagoons occupy an interzonal position, and are included in the Korean-Yellow Sea district of the South Japonic province of the Pacific Asian subtropical subregion of the West Pacific tropic region, while the open parts relate to the Asian low-boreal subregion. It should be noted that the flora and fauna of the Pacific American low-boreal subregion are also of mixed character as a result of the penetration within its limits of a large number of subtropic American elements, while typically boreal species penetrate the subregion mostly at considerable depths.

In the Atlantic boreal region, as well as in the Pacific region, 3 large biogeographical subdivisions can be distinguished. As a rule, they are considered to be of the rank of provinces. However, we consider them subregions based on analysis of the biogeographical structure of the modern biota of the Northern temperate/cold kingdom, taking regard of the rank of endemism and neglecting differences in the times of origin of modern physico-chemical conditions and of the related flora and fauna. As in the Pacific boreal region, so also 


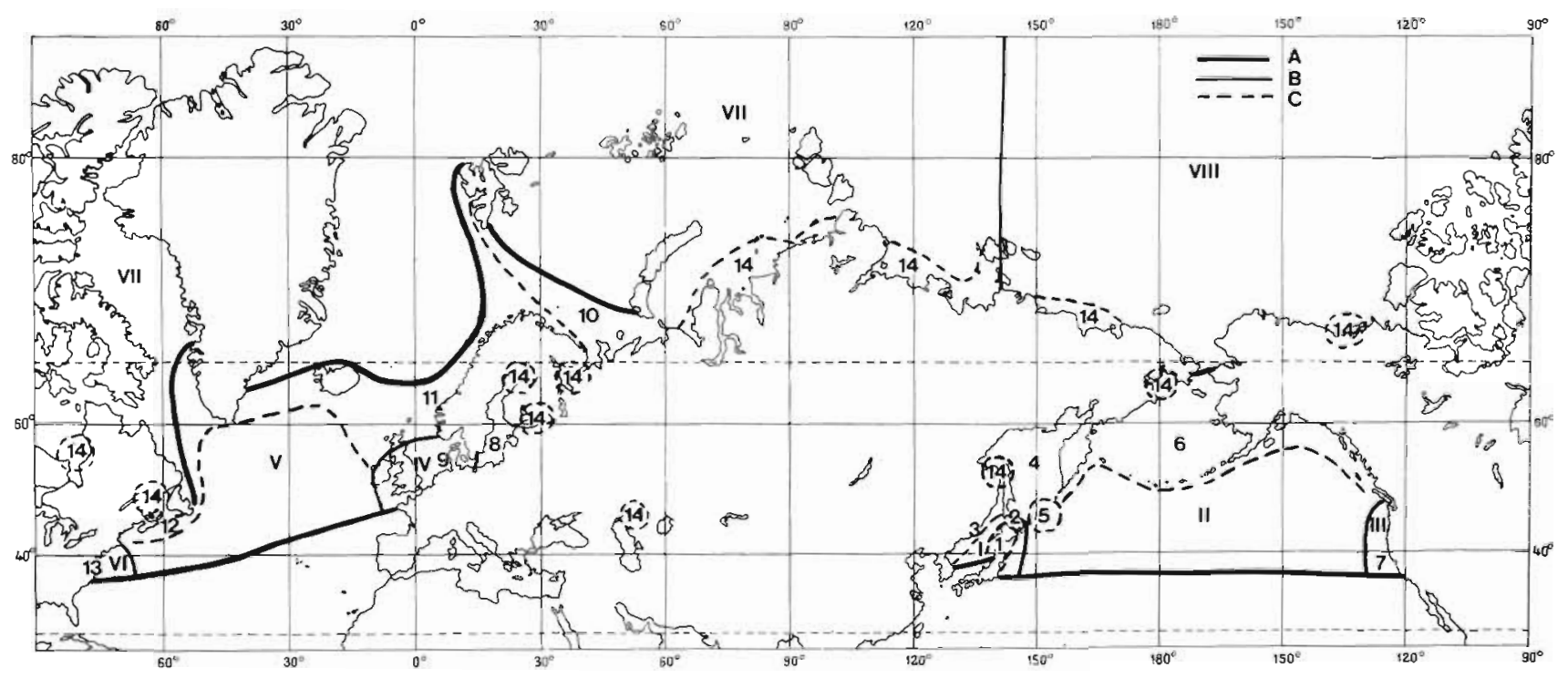

Fig. 6. Biogeographical division of the kingdom of temperate and cold waters of the Northern Hemisphere on flora-faunistic genetical basis. A: borders of regions; B: borders of subregions; $\mathrm{C}$ : borders of provinces. Pacific boreal region: - I - Pacific asian low-boreal subregion; 1, Northern japonic province; 2, Kuril-Sakhalin province; 3, Primorje province. II - Pacific high-boreal subregion: 4, Okhotsk Sea province; 5, Middle-Kuril province; 6, Aleutic-Kamchatka province. III - Pacific Oregonic low-boreal subregion: 7. Oregonic province. Atlantic boreal region: - IV - Celtic low-boreal subregion: 8, Baltic province; 9, North Sea province. V, Norwegian high-boreal subregion: 10, Barents Sea province; 11, Scandinavian province; 12, Newfoundland province. Arctic region: - VI - Virginian low-boreal subregion: 13, Virginian province. VII - Eurasian subregion. VIII - Amerasian subregion: 14, Estuary-Arctic interzonal province.

in the border provinces of the Atlantic boreal region the flora and fauna are of mixed character in their origin and, due to the position of water masses, the shoals and depths of one water basin may belong to different biogeographical regions. For example, in the Norwegian fjords, in the White Sea and in the eastern parts of the Barents Sea the border between the Atlantic boreal and the Arctic regions lies at depths of 30 to $40 \mathrm{~m}$, or, sometimes, even shallower.

In the Arctic region the Eurasian and Amerasian parts of the Arctic basin are considered subregions, which include provinces, occupied by the surface Arctic water mass (on average down to $200 \mathrm{~m}$ ), intermediate Atlantic-Arctic water mass (average depths from 200 to $800 \mathrm{~m}$ ), deepest Arctic water mass (from 800 to $1200 \mathrm{~m}$ down to pseudoabyssal) and by the interzonal brackish estuary-Arctic water mass. For each province some species and, sometimes, genera are endemic.

Beyond the limits of shelves, with increase in depth and decrease of differences in the temperature-salinity characteristics in different climatic zones, the borders of the biogeographical subdivisions tend to expand. The comparatively small biogeographical subdivisions including subregions disappear, though the limits of distribution of biogeographical regions, super-regions and kingdoms are preserved in general outline even at the greatest depths. The major biogeographical prin- ciples (provinciality, zonality, and historic-genetical approach) preserve their significance even in the biogeographical division of the bathyal and abyssal depths of the oceans. In the flora-faunistic trend the leading role is played by the position of water masses and their layers, which have a zonal distribution and are included into the azonal system of convection in the World Ocean (Sverdrup et al. 1942, Stepanov 1983).

\section{CONCLUSIONS}

The interrelated landscape and flora-faunistic approaches in biogeography considered here are based to a great extent on the analysis of the modern distribution of qualitative composition and quantitative development of species populations and higher taxa. As a result, biogeographical subdivisions with different geological age of origin are often accorded the same biogeographical rank. The biogeographical regions of the kingdom of tropic and subtropic waters have the greatest geological age of formation of the modern flora-faunistic composition and landscape appearance. The initial genera and, probably, even some species, which compose the modern biological pattern of the West-Pacific region of this kingdom, originated in the Cenomanian (ca 93 million yr ago). The high taxa of the 
most temporally stable kingdom of tropic waters served as sources for considerable part of the genetic material during the formation of the kingdoms of temperate and cold waters in both hemispheres. However, the kingdom of tropic waters is equal in rank with other kingdoms in modern biogeographical schemes. As regards the taxa composition and distribution of bioenergy, the biogeographical subdivisions of the subtropic latitudes in both hemispheres are controlled by more diverse and rich tropic subdivision. In the temperate/cold kingdoms of the World Ocean the older is that of the Southern Hemisphere, whose notal conditions and some elements of the flora-faunistic complexes started to form presumably near 36 million yr ago. In the recent tropho-dynamic biocycle of the macrosystem of temperate and cold waters of the Southern Hemisphere the leading role is played by notal waters with their high primary production, while a considerable part of the genepool seems to have formed near the Antarctic coasts.

The temperate/cold kingdom of the Northern Hemisphere appears to be the youngest in terms of formation of the modern hydrological and biological appearance. The oldest and the most diverse in this kingdom appears to be the Pacific boreal region (formation time about 14 million yr ago). The Atlantic boreal region originated much later (ca 5 million yr ago) and, while having Mediterranean-Lusitanic elements in its composition, is made up of nearly $75 \%$ of forms of Pacific origin. At the same time all authors attribute the same biogeographical rank to the Pacific and Atlantic regions. The Arctic biogeographical region is the youngest. Its present appearance started to form only 2.5 to 1.8 million yr ago. The recent energetic regime of Arctic waters is mostly under the control of the North Atlantic, which play the leading role in the AtlanticArctic tropho-dynamic macrosystem. At the same time most inhabitants of the Arctic region, including the most ancient and abundant ones, are of Pacific origin.

The vertical zonality of the World Ocean also needs further analysis from the historical and genetical points of view. For example, a number of organisms in the bathyal appear to be the most ancient representatives of present-day fauna, and there is a point of view that this part of the bottom profile is an ancient sea coast (Hosino 1975, 1986). In further investigations of the biogeography of the World Ocean more attention has to be paid to differences in the time and place of origin of various floras and faunas at different latitudes and depths, as well as to their succession and sources of formation.

Acknowledgements. The authors are thankful to reviewers of the paper for the valuable comments which assisted in improving the manuscript.

\section{LITERATURE CITED}

Addicott, W. O. (1969). Cenozoic marine paleontology of Pacific coasts. Prof. Pap. U.S. Geol. Surv. 50, N 1A, 138 pp.

Andriashev, A. P. (1974). On the vertical zonality system of the bottom marine fauna. Hydrobiology and biogeography of the shelves of cold and temperate waters in the World Ocean. Nauka Publishers, Leningrad, p. 6-7 (in Russian)

Appellöf, A. (1912). Invertebrate bottom fauna of the Norwegian Sea and North Atlantic. The depth of Ocean. Murray A. Hjort, London, p. 315-388

Babkov, A. I., Golikov, A. N. (1984). Hydrobiocomplexes of the White Sea. Zool. Inst. Acad. Sci of the USSR, Leningrad, 104 pp. (in Russian)

Baker, P., Burrel, I. (1977). The opening of Drake Passage. Mar Geol. 25 (1-3): 15-34

Beklemishev, K. V. (1969). Ecology and biogeography of pelagial. Nauka Publishers, Moscow (in Russian)

Beklemishev, K. V., Parin, N. V., Semina, G. I. (1977). Pelagial Oceanology. Biology of the Ocean Vol. 1. Nauka Publishers, Moscow, p. 219-261 (in Russian)

Berg, L. S. (1947). Bipolar distribution of organisms and the glacial epoch. Climate and life. Geographgiz, Moscow, p. 4-356 (in Russian)

Bogorov, V. G. (1967). Geographic zonation of the ocean. The Pacific Ocean. Biology of the Pacific Ocean, Vol. 1, Plankton. Geographiz, Moscow, p. 230-233 (in Russian)

Briggs, J. C. (1974). Marine zoogeography. McGraw-Hill, New York

Clements, F. E. (1905). Research methods in ecology. Lincoln, Nebr., p. 3-163

Clements, F. E (1916). Plant succession. Publs. Carnegie Instn, Washington, 242

Clements, F. E., Shelford, V E. (1939). Bioecology. J. Wiley \& Sons, New York

Dahl, E. (1908). Die Lycosiden oder Wolfspinnen Deutschlands und ihre Stellung im Haushalte der Natur. Nova acta Leopold. Carol. Deutsch. Naturforsch. 88; 174-678

Dall, W. H. (1893). A subtropical Miocene fauna in Arctic Siberia. Proc. U.S. natn. Mus. 16: $477-478$

Defant, A. (1929). Dynamische Oceanographie. Julius Springer, Berlin

Derjugin, K. M. (1915). The fauna of the Kola Bay and its environment. Acad Sci., Phys.-Math. Dept, Ser. 8,34 (1), 929 pp. (in Russian)

Dobrovolsky, A. D. (1961). On defining of water masses. Oceanology 1 (1): 12-24 (in Russian)

Ekman, S. (1934). Indo-Westpazifik und Atlanto-Ostpazifik eine tiergeographische Studie. Zoogeographica 2 (3): $320-374$

Ekman, S. (1935). Tiergeographie des Meeres. Akad. Verlagsgesellschaft, Leipzig

Ekman. S. (1953). Zoogeography of the Sea. Sidgwick and Jackson, London

Emiliani, C. (1956). Oligocene and Miocene temperatures of the equatorial and subtropical Atlantic Ocean. J. Geol. 64 (3) : $281-294$

Emiliani, C. (1961). Cenozoic climatic changes as indicated by the stratigraphy and chronology of deep-sea, cores of Globigerina ooze facies. Solar variations climatic changes and related geophysical problem. N.Y. Academy Sci., New York, p. 521-536

Emiliani, C., Flint, P. F. (1963). The Pleistocene record, The sea, Vol. 3. The earth beneath the sea history. Intern. publ., Vol. 7, Wiley \& Sons, New York

Flahaut, C., Schröter, C. (1910). Phytogeographische 
Nomenklatur. Berichte und Vorschläge. 3 Congr. Inter. Bot. Albert de Boeck, Bruxelles-Zürich, p. 1-28

Forbes, E. (1840). On the associations of Mollusca on the British coasts. Edinburgh Academic Annual for 1840 , Mem. Geol. Surv. G. Brit., I, 10 pp.

Forbes, E., Hanley, S. (1853). A history of British Mollusca and their shells. Van Voorst, London

Funnell, B. M. (1970). The Paleocene and Early Pleistocene of Norfolk. The geology of Norfolk. Yarwood and Funnel, Norwich, p. 270-376

Galkin, Yu. I. (1986). Long-term variations of the bottom fauna. Life and conditions of its existence in the benthal of the Barents Sea. Publ. Muzmansk mar. biol. Inst. Apatity, p. $43-52$

Golikov, A. N. (1963). Gasropods molluscs of the genus Neptunea Bolten. The fauna of the USSR, new series, 85 , Molluscs, 5 (1). Publ. Acad. Sci. USSR, Moscow-Leningrad (in Russian)

Golikov, A. N. (1973). Species and speciation in poikilothermal animals. Mar. Biol. 21: 257-268

Golikov, A. N. (1975). On the parallelism and convergence in the development of marine ecosystems. Biology of the shelves. Publ. Inst. mar Biol., Vladivostok, p. 30-32 (in Russian)

Golikov, A. N. (1980). Molluscs Buccininae of the world's oceans. The fauna of the USSR, 5 (2). Nauka, Leningrad (in Russian)

Golikov, A. N. (1985a). Stages and boundaries of the Cenozoic. Analysis of the course of geological time and development of the fauna of marine gastropods. Climate and the fauna of the Cenozoic. Proc. zool. Inst. Acad. Sci. USSR, Leningrad, Vol. 130, p. 31-52 (in Russian)

Golikov, A. N. (1985b). Zonation and organismic assemblages: comments on the comprehensive review by Pérès (1982). Mar. Ecol. Prog. Ser. 23: 205-206

Golikov, A. N., Averincev, V G (1977a). Biocoenoses of the upper shelf zones of the Franz Josef Land Archipelago and their distribution patterns. Explorations of the fauna of the seas, 14 (22), Nauka, Leningrad, p. 5-54 (in Russian)

Golikov, A. N., Averincev, V. G. (1977b). Distribution patterns of benthic and ice biocoenoses in the high latitudes of the polar basin and their part in the biological structure of the World Ocean. Polar oceans. Dunbar Arctic Inst. of North America, Calgary, Canada, p. 331-360

Golikov, A. N. Scarlato, O. A. (1967). Ecology of bottom biocoenoses in the Posset Bay (the Sea of Japan) and the peculiarities of their distribution in connection with physi$\mathrm{cal}$ and chemical conditions of the habitat. Helgolander wiss. Meeresunters. 15: 193-201

Golikov, A. N., Scarlato, O. A. (1968). Vertical and horizontal distribution of biocoenoses in the upper zones of the Japan and Okhotsk seas and their dependence on the hydrological system. Sarsia 34: 109-116

Golikov, A. N., Scarlato, O. A. (1973). Method for indirectly defining optimum temperatures of inhabitancy for marine cold blooded animals. Mar Biol. 20: 1-5

Golikov, A. N., Scarlato, O. A. (1976). On zonation of ecosys tems of the shelf. Abstracts of the Third Meeting of the AllUnion Hydrobiol. Soc., Riga, 1976, p. 201-203 (in Russian)

Golikov, A. N., Scarlato, O. A. (1979a). Influence of mussel aquaculture in the White Sea on the benthos of adjoing areas. Biology of the seas, Vol. IV Vladivostok, p. 68-75 (in Russian)

Golikov, A. N., Scarlato, O. A. (1979b). Some principles of landscape-geographic division of the shelf on ecological basis. Biology of the seas, Vol. V. Vladivostok, p. 3-16 (in Russian\}
Golikov, A. N., Scarlato, O. A. (1982). Coastal ecology of the Soviet Union. The encyclopedia of beaches and coastal environments. In: Schwartz, M. C. (ed.). Hutchinson Ross Publish. Co., Stronsburg, Penna, p. 772-780

Golikov, A. N., Scarlato, O. A., Buzhinskaya, G. N., Vas silenko, S. V., Golikov, A. A., Perestenko, L. P., Sirenko, B. I. (1986). Changes in benthos of the Possjet Bay (the Sea of Japan) over the past 20 years as a result of accumulation of organic matter in bottom sediments. Oceanology 26 (1): 131-136 (in Russian)

Golikov, A. N., Tzvetkova, N. L. (1972). The ecological principle of evolutionary reconstruction as illustrated by marine animals. Mar. Biol. 14: 1-9

Gressly, A. (1838). Observations géologiques sur le Jura soleurois. Nouv. Mem. Soc. Helvet. des Sci. nat., t. 2, $150 \mathrm{pp}$

Griesebach, A. (1838). Über den Einfluß des Klimas auf die Begrenzung der natülichen Floren. Linnaea 12, 40 p. 1-40

Gurjanova, E. F. (1951). Gammarids (Amphipoda, Gammaridae) of the Soviet seas and adjacent waters. Nauka Leningrad (in Russian)

Gurjanova, E. F. (1964). Zoogeographic zonation of bottom fauna of the World Ocean (bottom fauna of continental shelf). Physicogeographic atlas of the World. Publ. Acad Sci. USSR, Moscow, map 68 B (in Russian)

Gurjanova, E. F. (1972). Zoogeographic zonation of the Sea Explorations of the fauna of the seas, 10 (18), p. 8-21 (in Russian)

Gurjeva, E. N., Petrov, K. M., Sharkov, V V. (1976) Aeromethods in a geomorphological study on inner shelf and sea shores. Nauka, Leningrad (in Russian)

Hallam, A. (ed.) (1973). Atlas of palaeobiogeography. Elsevier Sci. Publ. Co., Amsterdam

Haq, B. U., Plemoli-Silva, I., Lohmann, G. P. (1977). Calcareous plankton palaebiographuc evidence for major climatic fluctuations in the early Cenozoic Atlantic Ocean. J. geophys. Res. 82: 3861-3876

Hayes, D. E., Frakes, L. A. (1975). General synthesis. Initial Reports of the Deep Sea Drilling Fdn 28: 919-942

Hopkins, D. M. (1972). The paleogeography and climatic history of Beringia during Late Cenozoic time. Int. J. Arctic Nord. Stud. 2: 121-1.30

Hosino, M. (1975). Eustacy in relation to orogenic stage. Tokai Univ. Press, Tokyo

Hosino, M. (1986). Marine geology. Nedra Publishers, Moscow (in Russian)

Humboldt, A. (1805). Essai sur la géographie des plantes accompagné d'un tableau physique des régions equinoxiales. Lavrault et Schoell, Paris

Hutchins, L. W. (1947). The bases for temperature zonation on geographical distribution. Ecol. Monogr. 17: 325-335

Kauffman, E. C. (1973). Cretaceous Bivalvia. Atlas of palaeobiogeography. Haltam, Amsterdam, p. 353-383

Kennett, J. P. (1977). Cenozoic evolution of Antarctic glaciation, the Circum-Antarctic ocean and their impact on global paleooceanography. J. geophys. Res. 3843-3860

Kinne, O. (1963). The effect of temperature and salinity on marine and brackish water animals. I. Temperature. Oceanogr. mar. Biol. A. Rev: 301-340

Kinne, $O$. (1964). The effect of temperature and salinity on marine and brackish water animals. II. Salinity and temperature - salinity combinations. Oceanogr mar. Biol. A. Rev.. 281-332

Kunne, O. (1970). Marine ecology, Vol. 1, Pt. 1, Chap. 3, Temperature. Wiley, London, p. 321-616

Kjellman, F. R. (1877). Uber die Algenvegetation des Murmanischen Meeres an der West-Küste von Novaja Semlja und Waigatsch. Nova acta R. Soc. Scient. Upsala, ser III, 1-86 
Krasilov, V A. (1977). Evolution and biostratigraphy. Nauka Publishers, Moscow (in Russian)

Kussakin, O. G. (1979). Marine brackish-water isopods (Isopoda) in cold and temperate waters of the northern hemisphere. The suborder Flabelligera. Nauka Publishers, Leningrad

Kvasov, D. D. (1985). Sharp fluctuations of climate in the Cenozoic and their influence on the evolution of faunas. Climate and fauna of the Cenozoic. Proc. zool. Inst. Acad. Sci. USSR, Leningrad, Vol. 130 p. 95-112 (in Russian)

Lindberg, G. U. (1972). Great fluctuations of the oceanic level during the Quaternary. Nauka, Leningrad (in Russian)

Lorenz, J. R. (1863). Physikalische Verhältnisse und Verteilung der Organismen in Quarterischen Golfe. Hof- $u$. Staatsdruck, Wien

Möbius, K. (1877). Die Auster und Austernwirtschaft. Berlin, $126 \mathrm{~S}$.

Monin, A. S. (1977). History of Earth. Nauka Publishers, Leningrad (in Russian)

Nesis, K. N. (1985). Oceanic cephalopods. Nauka Publishers, Moscow (in Russian)

Ortmann, A. E. (1896). Grünzüge der marinen Tiergeographie. G. Fisher, Jena

Orton, J. H. (1920). Sea temperature, breeding and distribution of marine animals. J. mar. biol. Ass. U.K. 12: 339-366

Petersen, C. G. J. (1913). Valuation of the sea. II. The anjmal communities of the sea bottom and their importance for marine zoogeography. Rep. Dan. Biol. Stn, 21: $1-44$

Petersen, C. G. J., Boysen-Jensen, P. (1911). Valuation of the sea. 1. Animal life on the sea bottom, its food and quality. Rep. Dan. Biol. Stn 20: 1-79

Petrov, K. M. (1974). Theoretic basis of landscape mapping of the bottom of marine shoals. Mapping of shelves. Geogr. Soc., Leningrad, p. 6-30 (in Russian)

Petrov, K. M. (1976). Geological history of the Bering Strait in the late Cenozoic. Beringia in the Cenozoic. Geogr Soc., Leningrad, p. 28-32 (in Russian)

Piccolli, G. (1984). Cenozoic molluscan associations of Mediterranean and south-east Asia: a comparison. Mem. di Sci. Geolog. Padova: 404-521

Runnström, S. (1929). Weitere Studien über die Temperaturanpassung der Fortpflanzung und Entwicklung mariner Tiere. Bergens Mus. Årsberetn (Naturvid.) 10: 1-54

Savin, S. M., Douglas, R. C., Stehli, F. G. (1975). Tertiary marine paleotemperatures. Bull Geol. Soc. Am. 86: $1499-1510$

Scarlato, O. A. (1981). Bivalve molluscs of the temperate latitudes of the western Pacific Ocean. Nauka Publishers, Leningrad (in Russian)

This review was submitted to the editor
Schmarda, L. (1853). Die geographische Verbreitung der Tiere. Die Tierwelt der Oceanis, Vol 3. C. Gerold u. John, Wien, 583-756

Schwerdtfeger, F. (1968). Demökologie. Structur und Dynamic tierischer Populationen. Parey, Hamburg

Shelford, $V$ E. (1932). Life zones, modern ecology and feilure of temperature summing. Wilson Bull. 44: 144-157

Shelford, $V$ E. (1945). The relative merits of the life zone and biome concept. Wilson Bull. 57: 248-252

Shelford, V. E. (1970). Some concepts of bioecology. Biologist 52: $59-71$

Shorygin, A. A. (1955). On biocoenoses. Bull. Moscow Soc. Naturalists, Dept. Biol. 60, 87-98 (in Russian)

Stepanov, V. N. (1983). Oceanosphere. Mysl, Moscow (in Russian)

Sverdrup, H. U., Johnson, M. W., Fleming, R. H. (1942). The oceans: their physics, chemistry, and general biology Prentice-Hall, New York

Tensly, A. C. (1935). The use and abuse of vegetational concepts and terms. Ecology: 284-307

Thorson, G. (1958). Parallel level-bottom communities, their temperature adaptation and their balance between predators and food animals. Perspectives in marine biology. Buzzani-Tzaverso, Univ. California Press, Berkeley, Los Angeles, p. 57-86

Tzvetkova, N. L. (1975). Coastal gammarids of the northern and Far Eastern seas of the USSR and adjacent waters. Genera Gammarus, Marinogammarus, Anisogammarus, Mesogammarus (Amphipoda, Gammaridae). Nauka, Leningrad (in Russian)

Vassilenko, S.V (1974). Caprellids of the seas of the USSR and adjacent waters. Identification key to the fauna of the USSR. Nauka, Leningrad, 107 (in Russian)

Vinogradova, K. L. (1984). On the history of formation of sea flora. 34th reading dedicated to the memory of Komarov. Nauka Publishers, Leningrad, p. 3-66 (in Russian)

Vorobjev, V P. (1949). Benthos of the Sea of Azov. Kzimizdat, Simpheropol (in Russian)

Wittaker, R. H., Levin, S. A., Root, R. E. (1973). Niche, habitat and ecotope. Am. Nat. 107: 321-338

Zenkevich, L. A. (1947). Fauna and biological productivity of the sea, 2. Seas of the USSR. Sovetskaya Nauka Publishers, Moscow (in Russian)

Zonenshain, L. P., Kuzmin, M. I., Moralev, V M. (1976). Global tectonics, magmatism and metallogeny. Nedra Publishers, Moscow (in Russian)

Zynova, A. D. (1962). On the phytogeographic zonation of the off coast area of the World Ocean. Abstracts of the Conference on joint study of fauna and flora. Zool. Inst., Acad Sci., Leningrad, 11 pp. (in Russian)

Manuscript first received: July 4, 1989

Revised version accepted: January 25, 1990 